www.czasopisma.marszalek.com.pl/pl/10-15804/npw

\author{
MaRCIN WICHMANOWSKI \\ Uniwersytet Marie Curie-Skłodowskiej \\ ORCID ID: https://orcid.org/0000-0001-57487946
}

\title{
Obraz kultury chłopskiej w myśli politycznej wybranych partii ludowych działających w II Rzeczypospolitej
}

\section{The image of peasant culture in the political thought of selected people's parties of the Second Polish Republic}

\section{Abstract}

Culture formed a significant element of political thought of every major political movement, both during the final years of partition of Poland, and after it regained its independence. The scope of interest of people's parties covered almost everything that had a rural context, relating to the many millions of peasants. The present article analyzes the program assumptions of the Polish People's Party "Piast" [Pol. Polskie Stronnictwo Ludowe "Piast"], Polish People's Party "Wyzwolenie" [Pol. Polskie Stronnictwo Ludowe "Wyzwolenie"], Peasant's Party [Pol. Stronnictwo Chłopskie] and the People’s Party [Pol. Stronnictwo Ludowe] relating to the aforesaid category of political sciences. These parties played a significant role in the history of people's movement, influencing the shape of the recreated Polish state during the interwar bi-decade. The political thought of people's parties aimed at bestowing the peasant's culture with both autonomous, and nationwide value. These ideological assumptions were included in the political programs of people's parties.

Keywords: political thought, culture, peasant's creativity, people's movement, Second Polish Republic 


\section{Крестьянская культура в политической мысли избранных народных (крестьянских) партий, действующих во Второй Речи Посполитой}

\section{Аннотация}

Культура являлась важным элементом политической мысли каждого из крупных политических движений периода конца Разделов и затем в независимой Польше. Интерес народных партий к культуре охватывал все, что имело деревенский, крестьянский контекст и относилось к многомиллионным крестьянским массам. Предметом анализа в данной статье являются программные положения Польской крестьянской партии «Пяст», Польской крестьянской партии «Освобождение» („Wyzwolenie”), Крестьянской партии и Народной партии (Stronnictwo Ludowe) относительно рассматриваемой политологической категории. В межвоенное двадцатилетие эти партии сыграли существенную роль в истории народного (крестьянского) движения и оказали влияние на строй возрожденной Польши. Политическая мысль народных (крестьянских) партий стремилась придать крестьянской культуре ее автономные и, одновременно, общенародные ценности. Такие идеологические положения вошли в политические программы народных (крестьянских) партий.

Ключевые слова: политическая мысль, культура, крестьянское творчество, народное (крестьянское) движение, Вторая Речь Посполитая

\section{Uwagi wstępne}

Kultura była ważnym elementem myśli politycznej każdego z większych - ruchów politycznych w końcowym okresie zaborów i w Polsce niepodległej (Wichmanowski, 2013b, s. 8). Przedmiotem analizy będą artykuły prasowe, założenia programowe, dokumenty i wypowiedzi polityków Polskiego Stronnictwa Ludowego „Piast”, Polskiego Stronnictwa Ludowego „Wyzwolenie", Stronnictwa Chłopskiego i Stronnictwa Ludowego wobec zagadnienia zawartego $\mathrm{w}$ tytule. $\mathrm{W}$ dwudziestoleciu międzywojennym partie te odegrały istotną rolę w dziejach ruchu ludowego i wpłynęły na kształt odrodzonej Polski. Druga Rzeczpospolita stanowiła zamknięty okres historyczny, szczególnie ważny dla ruchu ludowego co najmniej z dwóch powodów: po pierwsze - ludowcy osiągnęli największe znaczenie polityczne, 
po drugie - wykrystalizowała się nie tylko myśl polityczna, ale też uogólnione zostały zasady światopoglądu agrarnego ${ }^{1}$.

Niezbędne dla ukazania problemu było zastosowanie metod i technik badawczych swoistych dla eksploracji badań nad myślą polityczną; przede wszystkim analiza świadectw i śladów myśli politycznej partii ludowych. Takie podejście badawcze pozwoliło na uchwycenie swoistości i nietypowości kategorii w myśli politycznej ruchu ludowego, jaką była kultura chłopska. Podstawową bazę źródłową dla opracowania tematu stanowiła prasa ludowa, programy polityczne partii oraz archiwalia. Podczas realizacji tematu okazały

${ }^{1}$ Myśl polityczna jest istotnym elementem rzeczywistości politycznej, będącej przedmiotem badań politologicznych. Należy w niej dostrzegać nie tylko składnik świadomości, ale również intelektualną podstawę procesów decyzyjnych. Refleksja nad myślą polityczną jest niezbędna, aby zrealizować określoną przez Andrzeja Garlickiego dyrektywę: „Historyk, jeśli chce zrozumieć i ocenić postępowanie ludzi przeszłości, nie może ograniczać się jedynie do odtwarzania ich działań, ale musi dążyć do zbadania motywów tych działań.A to właśnie oznacza również rozpatrywanie możliwości niespełnionych”. Zob. szerzej: Garlicki, 1981, s. 6. To przesłanie metodologiczne, na co zwrócił uwagę Waldemar Paruch (2005, s. 9), obowiązuje również politologów, przynajmniej z tej ogólnej racji, że polityka, jako konstytutywny składnik rzeczywistości politycznej, posiada związane ze sobą wymiary: praktyki i refleksji. W obu z nich występuje myślenie polityczne, którego efektem jest myśl polityczna. Prowadzone współcześnie badania nad kształtem, charakterem i dziejami myśli politycznej przynoszą liczne definicje, które z reguły wskazują podmiot dociekań naukowych, wyznaczają dziedzinę zainteresowań oraz sposoby artykulacji poglądów politycznych wybranych ruchów politycznych, partii i ich ideologów. Podążając tym tropem, można zgodzić się z badaczami, którzy rozumienie pojęcia „myśl polityczna” traktują szeroko. W ten sposób należy traktować termin „myśl polityczna” użyty w tytule artykułu, który został sformułowany „w istocie wszelkiej formy refleksji nad rzeczywistością polityczną”. Zob. szerzej: Jachymek, Paruch, 2001, s. 10-12; Jachymek, 1983, s. 9; Paruch, 1997, s. 12-14; 1999, s. 27-40; 2015, s. 157-174; 2005, s. 9-11; 2004, s. 11-12; 2006, s. 207-214; 2009, s. 37-46; Wójcik, 1992, s. 7; Maj, Wójcik, 2008, s. 7; Olszewski, 2015, s. 153-173; Zieliński, 1975, s. 7-26; Wapiński, 1987, s. 52; 1990, s. 169-178; Łuczak, 1982, s. 6; Zakrzewski, 1988, s. 121-134; Czarnota, 1988, s. 271; Skarzyński, 1990, s. 9-27; 1992, s. 107-119; Król, 1998, s. 5-6; Jajecznik, 2006, s. 255-259. Do kręgu myśli agrarystycznej zaliczyć należy te koncepcje teoretyczne, w których uznaje się jakąś nadrzędność specyficznie zorganizowanego podukładu agrarnego w bycie społecznym. W Polsce agraryzm jako swoisty system poglądów związany był z ideologiczno-programową aktywnością ruchu ludowego. W związku z tym o agraryzmie jako jednoznacznie wyodrębnionej myśli społeczno-politycznej można zasadnie mówić począwszy od pierwszych lat 30. XX wieku. W tamtym bowiem czasie rozpoczęły się systematyczne prace nad sformułowaniem własnej ideologii i programu polskiego ruchu ludowego. Ukoronowaniem było przyjęcie w 1935 roku przez Kongres SL programu, którego podstawą była myśl agrarystyczna (Chrobak, 1998, s. 23, 29). 
się wielce pomocne rozważania znajdujące się w artykułach i monografiach badaczy ruchu ludowego, jak również myśli politycznej.

Badany problem wymagał przede wszystkim wyjaśnienia podstawowych pojęć. Kultura chłopska, ludowa - zastosowano w artykule zamiennie, jednak ich rozumienie przysparzało pewnych trudności. Należało wybrać jedną z licznych definicji kultury i sposób jej interpretowania. Określenie kultura chłopska było niejednokrotnie definiowane przez zajmujące się nią nauki, a różnice wynikały zarówno ze stanu badań jak i koncepcji metodologicznych, jakie bliskie były tym, którzy badania prowadzili. Dla potrzeb opracowania przyjęto szerokie rozumienie kultury, jako całokształtu duchowego i materialnego dorobku społeczeństwa ${ }^{2}$. Kultura ludowa bywa najczęściej określana jako suma wytworów ukształtowanych w ramach wiejskiej społeczności lokalnej. Czasem traktuje się ją jako zbiór wzorów, norm i wartości rozwiniętych przez warstwę chłopską. W swych podstawowych zrębach została uformowana w okresie kształtowania się ustroju feudalnego i stanowego różnicowania społeczeństwa, jako dorobek chłopstwa, które wówczas stanowiło już, obok mieszczan i rycerstwa, grupę odrębną. Na kulturę ludową - chłopską, składają się kolejno: pierwiastki archaiczne, elementy oryginalne, zapożyczenia wewnątrzetniczne i interetniczne. W przeciwieństwie do kultury narodowej, kultura ludowa wykazuje poważne nieraz odmienności regionalne, będące efektem względnej izolacji i niejednakowych warunków środowiskowych, m.in. gwara, dialekty, stroje, folklor, sztuka i rzemiosło (Bukraba-Rylska, 2008, s. 476-477). Natomiast pojęcie „lud”3 związane jest

2 Pojęcie „kultura”, w najszerszym rozumieniu, jest całokształtem duchowego i materialnego dorobku społeczeństwa. Definicje kultury składają się na jej szerokie pojmowanie. Kultura jest zespołem wartości (moralnych, prawnych itp.) oraz wzorów i wzorców (zachowań, instytucji itp.), które pragniemy propagować i do których chcemy wprowadzać jednostki i grupy społeczne przez wzmaganie i budzenie odpowiednich zainteresowań i potrzeb. Artystyczne rozumienie kultury: kultura = sztuka; rozumienie potoczne, wartościujące: kultura = grzeczność, dobre wychowanie; rozumienie antropologiczne: kultura = dorobek cywilizacyjny. Zob. szerzej m.in.: Kopaliński, 1967, s. 419; Wokół...; Kultura...; Kultura jako... Kultura ludowa, tu chłopska - tworzenie jej i przekaz dokonuje się w kontaktach bezpośrednich. U jej podłoża leży żywa więź społeczna (Kowalski, 1996, s. 27).

3 Analizując różne określenia pojęcia „lud”, jakie można spotkać w dokumentach źródłowych, zauważa się, że przez „lud” rozumiano początkowo wszystkich ludzi pracy. Używano jednak często pojęcia „lud włościański” (Wichmanowski, 2017, s. 125). W sformułowaniach deklaracji ideowej Związku Młodzieży RP z 1931 roku można dostrzec odejście 
z wydzielonym już w średniowiecznej Europie stanem chłopskim (Chrobak, 1998, s. 33).

Polski ruch ludowy i jego samodzielna myśl polityczna zaczęły kształtować się na przełomie XIX i XX wieku - w czasie, gdy na gruncie europejskim powstawały już partie polityczne o charakterze masowym ${ }^{4}$. Ziemie polskie, wtłoczone w trzy różne organizmy państwowe, wykazywały specyfikę w działalności stronnictw ludowych. Ludowcy pod zaborem rosyjskim działali w warunkach ostrych represji politycznych. Pod zaborem pruskim koncentrowano się na obronie polskiego stanu posiadania. Natomiast ruch ludowy w Galicji rodził się najwcześniej, wykorzystując znaczne swobody polityczne i narodowe, gwarantowane konstytucją z 21 grudnia $1867 \mathrm{roku}^{5}$. Ludowcy galicyjscy działali legalnie, brali udział w kampaniach wyborczych do galicyjskiego Sejmu Krajowego we Lwowie i wiedeńskiej Rady Państwa. W takich warunkach mógł powstać w 1903 roku rzeszowski program Polskiego Stronnictwa Ludowego, będący programem nowoczesnej partii. Z PSL, po rozłamie w grudniu 1913 roku, wzięło początek w 1914 roku Polskie Stronnictwo Ludowe „Piast” (Jachymek, 2002, s. 28, 30-31; Garlicki, 1966; Wojdyło, 1985, s. 8-19; Cimek, 2007, s. 13). PSL „Piast” było chłopską partią polityczną, która odegrała istotną rolę w dziejach całego ruchu ludowego. Jego przywódcą był Wincenty Witos (Wichmanowski, 2019, s. 315-317).

od rozumienia pojęcia „lud” jako ogółu ludzi pracy, ograniczając je do ludu wiejskiego chłopów (Hampel, 2002, s. 713). Dla potrzeb artykułu określenia kultura chłopska i ludowa zastosowano zamiennie.

4 Ruch Ludowy, według definicji Jana Jachymka (1993; 2001, s. 221, 223), to całokształt samodzielnej pracy różnych organizacji: politycznych, gospodarczych, kulturalno-oświatowych i innych, służących Polsce oraz godnemu w niej miejscu chłopów. Prymarnymi komponentami ruchu były przede wszystkim stronnictwa ludowe, ale również, w dalszej kolejności organizacje młodzieży wiejskiej, kółka rolnicze, straże pożarne, różnego rodzaju organizacje spółdzielcze i rolnicze działające na wsi, a także uniwersytety ludowe, teatry, chóry oraz wiele innych. Zob. też: (Wichmanowski, 2019, s. 314-315).

5 Monarchia austriacka w 1867 roku przekształciła się w Austro-Węgry. Z państwa absolutystycznego stała się konstytucyjnym. W konstytucji dla Polaków najważniejszy był punkt trzeci. Postulowano w nim rozszerzenie uprawnień Sejmu Krajowego o prawo organizacji władz administracyjnych i sądowych, kodyfikację prawa karnego i wekslowego oraz prawo do osobnego funduszu krajowego. Natomiast 4 czerwca 1869 roku język polski stał się w Galicji językiem urzędowym władz administracyjnych i sądownictwa. Zob. szerzej: Łazuga, 2013, s. 31, 89, 92. 
Ludowcy pod zaborem rosyjskim w 1915 roku połączyli się, tworząc Polskie Stronnictwo Ludowe, które w 1918 roku od tytułu organu prasowego partii przyjęło nazwę „Wyzwolenie”. Prezesami Zarządu Głównego PSL „Wyzwolenie” byli kolejno Błażej Stolarski, Stanisław Thugutt, Jan Dąbski, Maksymilian Malinowski. W pierwszych latach niepodległości PSL „Wyzwolenie" zajmowało jedno z czołowych miejsc wśród partii politycznych byłego Królestwa Polskiego (Cimek, 2007, s. 19-20, 37, 39, 225).

Liczącą się partią ludową było działające od roku 1926, niespełna sześć lat w życiu politycznym państwa polskiego, Stronnictwo Chłopskie. Twórcą i głównym ideologiem SCh był Jan Dąbski. W programie SCh z 1927 roku podkreślono: „Stronnictwo Chłopskie jest klasową organizacją chłopów o charakterze radykalnym, powołaną do obrony ich politycznych, gospodarczych, społecznych i kulturalnych interesów" (Podgajna, 2011, s. 21).

W dniu 15 marca 1931 roku odbył się w Warszawie kongres, na którym dokonano oficjalnego połączenia PSL „Piast”, PSL „Wyzwolenie” i SCh. Nowa partia, z W. Witosem na czele, przyjęła nazwę Stronnictwo Ludowe ${ }^{6}$, jej organem prasowym został „Zielony Sztandar”. SL było najliczniejszą polską partią polityczną w latach trzydziestych XX wieku (Wichmanowski, 2010, s. 78-79).

\section{Kultura chłopska w programach stronnictw ludowych, prasie i koncepcjach polityków}

W okresie dwudziestolecia międzywojennego zakres zainteresowania stronnictw ludowych kulturą dotyczył wszystkiego co miało kontekst wiejski, chłopski. Chłopi należeli do podstawowych, liczebnie największych i historycznie najstarszych warstw społecznych.

Kultura, a przede wszystkim sztuka ludowa była w pewnym stopniu estetycznym wyrazem stosunku do ziemi, była jakby apoteozą pracy chłopskiej, unaocznieniem $i$ artystycznym wyrazem obyczajowym, magicznym czy religijnym stosunkiem do ziemi, pokazaniem, że siła chłopa wynika z samych sił przyrody (...). Chłop przez swoje obrzędy, przez pieśni, muzykę, przez obyczaje, był włączony

6 Więcej informacji na temat SL można znaleźć w Archiwum Akt Nowych w Warszawie, sygn. 110/I, II, V, Zespół: Stronnictwo Ludowe 1932-1939 (mf. 2530). 
w wielki proces przyrody przetwarzający swoją pracą ziemię (...) w chleb i żywność. Sztuka i inne składniki kultury chłopskiej były dla niego potwierdzeniem, że jego praca jest składnikiem wielkiego procesu przyrody (...) (Szmyd, 1996, s. 13,15$)$.

Uprawa ziemi i relacje, w jakie wchodził chłop ze środowiskiem przyrodniczym, były przedmiotem szczególnego zainteresowania agrarystów. To czynniki przyrody wyznaczały rytm pracy rodziny chłopskiej. Chłopi sytuowali się nisko w ramach struktury społecznej. Polityczna podległość przeplatała się z podległością kulturalną. Kultura chłopska była kulturą zamkniętą, ale pozostawała $\mathrm{w}$ różnych związkach z kulturą miejską, masową czy wysoką. Teoretycy agraryzmu poszukiwali w tradycyjnej kulturze chłopskiej, prymarnych treści charakterystycznych dla kultury narodowej (Chrobak, 1998, s. 38-39).W opinii ideologów ludowych, chłop przez wieki spełniał istotną funkcję kulturotwórczą; był kreatorem różnych form sztuki oryginalnej - sztuki ludowej, która realizowała wiele ważkich zadań w ramach kultury narodowej, znacząco ją bogacąc, wpływając korzystnie na jej ciągłość i tożsamość. Wytworzył unikalny etos ludowy, właściwy sobie obyczaj, swoisty, historycznie trwały typ religijności. Myśl chłopska skupiona wokół ruchu ludowego, od zarania tego ruchu, wskazywała oprócz tworzenia bogatego programu oświatowego dla wsi na konieczność intensywnego wprowadzania różnych form życia kulturalnego. Programy formułowane w tym zakresie ulegały ewolucji, były coraz obszerniejsze i merytorycznie doskonalsze (Strzelecki, 2008).

Kierownictwo PSL „Piast”, wywodzące się z galicyjskiego ruchu ludowego, przywiązywało do kultury chłopów wielką wagę. Z satysfakcją twierdzono, że „Przedwojenna Galicja posiadała liczną inteligencję chłopskiego pochodzenia" (Wichmanowski, 2017, s. 213). W dokumentach partii wytworzonych w II RP kultura chłopska zajmowała znaczącą pozycję. Uważano, że w nowych warunkach społeczno-politycznych dobra kulturalne, takie jak oświata, nauka, sztuka, powinny stać się dostępne dla ogółu obywateli. Wśród postulatów zawartych w programach znaczącą pozycję zajmowała deklaracja ochrony i rozwoju kultury chłopskiej. Stronnictwo zobowiązało się „(...) organizować wszelkie instytucje kulturalno-oświatowe (uniwersytety ludowe, towarzystwa oświatowe, domy ludowe, kółka rolnicze itd.) niosąc ludowi 
prawdziwą wiedzę" (Program Polskiego Stronnictwa Ludowego Piast..., 1920, s. 180).

W programie PSL „Wyzwolenie” zaznaczono, że „Lud polski, w warstwie chłopskiej skupiający się, jest nie tylko olbrzymią większością narodu; jest on nadto praźródłem jego myśli i charakteru, skarbnicą jego najistotniejszych wartości duchowych i moralnych (...), a obowiązkiem państwa jest (...) popieranie twórczości artystycznej, zwłaszcza twórczości ludowej” - podkreślono (Program Polskiego Stronnictwa Ludowego Wyzwolenie..., 1925, s. 229-230, 236). Posłowie PSL „Wyzwolenie” zobligowali klub parlamentarny Stronnictwa do zdecydowanego zajęcia się sprawami oświaty i kultury wiejskiej (Wichmanowski, 2013a, s. 51).

Stronnictwo Chłopskie zapowiadało, że „(...) otoczy szczególną opieką kulturę i sztukę opartą na pierwiastkach ludowych” (Program Stronnictwa Chłopskiego..., 1927, s. 285). Krytykowało wszelkie działania, których celem było pogłębianie „ciemnoty i analfabetyzmu” na wsi. SCh oświatę i kulturę uważało za podstawę siły państwa. Dzięki demokratyzacji kultury zdaniem ideologów SCh, chłopi mogli być świadomymi uczestnikami życia narodowego, ponieważ „(...) wyżywić i obronić ojczyznę może nie tylko silny liczebnie, ale silny kulturalnie i oświatowo, tak wysoko, by rozumiał to wszystko co się wokół niego dzieje, co, jak i dlaczego robi się w państwie i na świecie. Nie wystarczy tu umiejętność czytania i pisania, ale musi być świadomość życia społecznego, gospodarczego i politycznego" (Kolanko, 1927, s. 3).

Kwestia kultury chłopskiej została szeroko ujęta w programie SL z 1931 roku. Napisano, że partia

(...) otoczy opieką wszelkie organizacje i instytucje mające na celu badanie i rozwijanie kultury ludowej, a przez to dążące do wzbogacenia kultury narodowej. Obrzędy i zwyczaje lokalne i ogólnonarodowe, stroje ludowe, zdobnictwo i budownictwo, słowem wszystko, co nadaje naszej wsi swoiste cechy, co świadczy o jej prastarej przeszłości i twórczości kulturalnej, znajdzie również życzliwą opiekę w Stronnictwie Ludowym. (...) [SL, M.W.] uważa za swój obowiązek otoczenie opieką wszystkich instytucji i stowarzyszeń mających na celu rozwój życia zbiorowego oraz podnoszenia kultury (...) wsi, jak np. domy ludowe, uniwersytety ludowe, czytelnie, biblioteki, teatry, chóry, kapele, (...) itd. (Program Stronnictwa Ludowego..., 1931, s. 302-303). 
Założenia myśli agrarystycznej, rozwinięte w pracach Stanisława Miłkowskiego, Leona Lutyka, uchwałach i deklaracjach SL, stały się podstawą programu Stronnictwa Ludowego uchwalonego w dniach 7-8 grudnia 1935 roku (Hampel, 2002, s. 713). Agraryzm był ważnym źródłem myśli politycznej SL. W rozumieniu S. Miłkowskiego był ideologią warstwy chłopskiej. Chłopskie widzenie świata i życia, stanowiło bowiem przesłankę nowych rozwiązań ustrojowych, politycznych, kulturalnych, moralnych (Chrobak, 1998, s. 74). W I rozdziale programu Lud wiejski a naród i państwo zostało zawarte stwierdzenie: „Ludność wiejska ze względu na swą liczebność, swoją tężyznę fizyczną i moralną, wynikającą ze związku jej z ziemią, oraz wartości narodowe i państwowe, jest uprawniona do uważania się za naturalnego gospodarza Polski. Toteż Stronnictwo Ludowe, jako polityczna reprezentacja tej ludności, obejmuje okiem swym i swoją troską nie tylko klasowe interesy wsi, ale całość interesów narodu polskiego i stworzonego przezeń tysiącletnią pracą państwa”. W rozdziale VIII Oświata zwrócono uwagę na powinności państwa w dziedzinie oświaty i kultury. „Do zadań państwa w dziedzinie oświaty i kultury należy udostępnienie najszerszym rzeszom wszystkich dóbr narodowego dorobku kulturalnego. Rozpowszechnienie i pogłębienie oświaty stawiamy na równi z zabezpieczeniem obrony państwa" (Program Stronnictwa Ludowego..., 1935, s. 313, 317).

Ideolodzy stronnictw ludowych zmierzali do nadania kulturze chłopskiej jej wartości autonomicznych i równocześnie ogólnonarodowych. Podkreślali, że należy dążyć do tego, by tradycja chłopska była źródłem twórczości ludzi wsi w zakresie poezji, muzyki, obrzędowości, sztuki zdobniczej, sztuki teatralnej i innych. Sztuka ludowa, ich zdaniem, zapewniała narodowi kulturową tożsamość. Takie założenia mieściły się w programach politycznych partii ludowych. Odwoływano się w nich do odrębności kulturowej warstwy chłopskiej i sytuacji chłopów w społeczeństwie.W działalności partii ludowych można zauważyć wiele wysiłku nad podniesieniem godności chłopów, poprzez docenienie ich wkładu do kultury narodowej. Ten aspekt ideologii ludowców znajdował najbardziej spektakularny wyraz w postawie W. Witosa, Macieja Rataja, S. Thugutta, J. Dąbskiego i innych polityków stronnictw ludowych. Przez świadomą akcję informacyjną, skierowaną w stronę kultury ludowej, starano się ukazać niedocenione wartości kulturotwórcze chłopów w przeszłości i w Polsce niepodległej (Szmyd, 1996, s. 13). Doświadczenie własnej tożsamości 
kulturowej i narodowej oraz poczucie krzywdy historycznej i osobistej aktywizowało społeczności chłopskie. To właśnie na tym tle powstał polityczny ruch ludowy i będący pod jego wpływem społeczno-kulturalny ruch młodoludowy i agrarystyczny. Ruch ten przyczynił się znacznie do samouświadomienia społeczno-kulturalnego chłopów (Chrobak, 1998, s. 67-68).

Wokół kultury chłopskiej okresu dwudziestolecia międzywojennego widoczne były różnorodne poczynania. Jedne z nich nawiązywały do idei i działań powstałych już wcześniej, inne tworzyły się wraz z nową rzeczywistością. Były poczynania odgórne, inteligenckie, niemające bezpośredniego związku z politycznym ruchem ludowym, skierowane na kulturę chłopską jako przedmiot badań naukowych. Były też odgórne działania inteligencji twórczej, przepojone ideą ludowości i jej roli w tworzeniu kultury narodowej. Zaznaczyły się w sztuce, literaturze, w działalności teatralnej. Zjawisko to można nazwać ludowością elitarną. Idea i działania, związane z politycznym ruchem ludowym, to ludowość chłopska. Była przede wszystkim wyrazem politycznej i społeczno-kulturalnej emancypacji chłopów (Burszta, 1985, s. 258-259, 269; Kuranc-Szymczak, 2019, s. 221-222; Turkowski, 1983, s. $87-98)$.

Politycy stronnictw ludowych domagali się wprowadzenia kultury ludowej do kultury ogólnonarodowej. Koncepcja wiązała się z ogólną ideą agraryzmu jako kierunku zarówno gospodarczego, jak i kulturalnego. Deklarowali poparcie dla twórców ludowych, postulowali opiekę państwa nad instytucjami krzewiącymi na wsi kulturę, a zwłaszcza domami ludowymi, uniwersytetami ludowymi, bibliotekami, teatrami i instytucjami badającymi kulturę ludową. Zwracano uwagę na małe zainteresowanie władz polskich rozwojem kultury ludowej, szczególnie na ziemiach Wschodniej Małopolski. Profesor Franciszek Bujak, wybitny historyk społeczno-gospodarczy, propagujący teorię agraryzmu i wynikającą z niego idę ludowości podkreślił, że „(...) kultura polska powstawała z kultury ludowej, odnawiała się i odmładzała się z niej ciągle”. W gazecie „Piast”, organie prasowym PSL „Piast”, podkreślono, że „największa masa ludzka - chłopi, nie mieli (...) możności rozwijania własnej kultury (...)”, a polskiej „(...) kulturze (...) ton nadawała najpierw szlachta - (...) później miasta" (Bogusławski, 1923, s. 8; P.B., 1935, s. 3; Bujak, 1939, s. 489-490; Redakcja, 1929a, s. 2; J.B., 1937, s. 8; Szaflik, 1970, s. 71). 
Ważnym elementem kultury wiejskiej były występy chórów, orkiestr i teatrów ludowych, a także odczyty, wycieczki, kursy zawodowe i inne, których tradycja sięgała okresu zaborów. Pisali o tym głównie terenowi korespondenci gazet ludowych. Okazją do występów stawały się popularne rocznice, uroczystości świeckie i religijne, festyny i zabawy; przy okazji kwestowano na cele kulturalne i oświatowe wsi. W majowych numerach „Piasta” z 1919 roku informowano czytelników między innymi o tym, że w licznych powiatach Małopolski, uroczyście obchodzono rocznicę uchwalenia Konstytucji Trzeciego Maja. Chłop z limanowskiej wsi w liście do redakcji w 1927 roku napisał, że jego wieś wcześniej nie uznawała obchodów świąt narodowych, „(...) dopiero teraz zaczynają wchodzić w życie. Bardzo to pięknie wygląda, gdy my włościanie garniemy się do (...) kultury (...)” - zaznaczył (Lubas, Czarnota, 1919, s. 8; Redakcja, 1919c, s. 14-15; Liszka, 1927, s. 7).

Ludowcy - organizatorzy imprez przykładali dużą wagę do oprawy artystycznej. Największy podziw wzbudził pułk chłopów - krakowiaków uzbrojonych w kosy, podczas obchodów 138. rocznicy przysięgi Tadeusza Kościuszki na rynku krakowskim (A.P., 1932, s. 3; Redakcja, 1919d, s. 1-2). Autorzy opisów akcji kulturalno-oświatowych społeczności wiejskiej, zwracali szczególną uwagę na tradycyjne zwyczaje i obrzędy ludowe. Ważnym wydarzeniem były odpusty parafialne z symboliką ludową, podczas których „Dziewczęta wiozą na furach wieńce i zioła, wjeżdżają do miasta $\mathrm{z}$ fantazją i śpiewem (...)".W uroczystościach ludność występowała zwykle w strojach regionalnych.

Działacze partii ludowych popierali zakładanie na wsi kółek dramatycznych, oświatowych, czytelni i bibliotek, zbieranie funduszy na budowę domów ludowych. Organizowali uroczyste święcenia sztandarów ludowych i kamieni węgielnych pod budowę domów ludowych i spółdzielczych. Związek Teatrów i Chórów Włościańskich uruchomił we Lwowie kurs dramatyczny dla wyszkolenia reżyserów amatorskich zespołów teatralnych. Dzięki teatrom ludowym wprowadzono kulturę ludową do kultury narodowej i zapoznano z nią społeczność miejską. Zespół teatralny Uniwersytetu Ludowego w Gaci, prowadzony przez Zofię Solarzową, występował na scenach teatrów Lwowa, Krakowa, Przemyśla, Jarosławia, Łodzi i Warszawy. Ignacy Solarz, twórca uniwersytetów ludowych, członek SL, z szacunkiem odnosił się do tradycji chłopskich, przejawów kultury ludowej i starych zwyczajów, a nawet wiele 
z nich, zanikających, usiłował ożywić. Solarz był orędownikiem agraryzmu. W koncepcjach Solarza nie było rozdziału między wartościami kultury ludowej, narodowej i ogólnoludzkiej. Jego żona prowadziła z młodzieżą wiejską zajęcia artystyczne: śpiew, tańce, wykłady z literatury, zajęcia teatralne (Dejworek, 1965, s. 39, 47).

W gazetach stronnictw informowano, że we wsiach „(...) w każdą niedzielę czy święto odbywają się zjazdy, zgromadzenia publiczne (...) i występy teatrów amatorskich. (...) poranki literackie, na których występują literaci chłopscy”. W Monasterzu powstało Towarzystwo Teatru i Chóru Włościańskiego oraz czytelnia Towarzystwa Oświaty Ludowej. Na łamach gazet ludowcy zwracali się do chłopów „(...) znad Wisły, Odry i Niemna”, by propagowali „(...) czyste słowo polskie, (...) pieśń polską, (...) stroje narodowe, (...)” (Babinianin, Czytelnik, 1919, s. 10; Dunikowski, 1919, s. 8; Dziewczyna wiejska, Przyszowa, 1919, s. 14; Redakcja, 1919a, s. 1-3; 1919b, s. 3; 1922, s. 9-10; 1930a, s. 3; 1935d, s. 3; 1935e, s. 2). Zamieszczali informacje o powstawaniu młodzieżowych kół kulturalno-oświatowych, w których działały: ochotnicze straże pożarne, grupy przysposobienia wojskowego, ogniska sportowe, chóry, związki teatralne. Dochód z wiejskich imprez był przeznaczony głównie na cele kulturalne i oświatowe $w^{7} i^{7}$. Do propagowania kultury wśród społeczności wiejskiej włączali się studenci i inteligencja wiejska. Na prowincji, w środowisku oddalonym od centrum życia teatralnego czy literackiego, to szkoła, oprócz funkcji edukacyjnych, pełniła ważne zadania kulturotwórcze (Moskal, Jarosz, 1926, s. 10-11; Wieski, 1929, s. 3; Bożek, 1937, s. 4; Budrewicz, 1996, s. 221-225).

Sympatycy ruchu ludowego wyrażali zachwyt nad polskimi strojami ludowymi, po których można było poznać, „z której okolicy właściciel pochodził”, a „(..) którego to stroju wieś nasza (...) się wstydzi i systematycznie wyzbywa. A szkoda wielka (...)”, ponieważ „Piękne są sukmany staropolskie, czapy, gorsety, buty z cholewami”. Zwrócono uwagę, że „stroje ludowe zachowała głównie ludność Śląska, powiatów z krakowskiego i części Królestwa”. Zachwycano się również wiejską architekturą. (Pluta, 1919, s. 3-4; Redakcja,

7 Materiały od czytelników nadsyłane do redakcji „Piasta”, wiersze, pieśni, korespondencja, konkursy na hymn ludowy z lat 1933-1939 znajdują się w zbiorach Archiwum Zakładu Historii Ruchu Ludowego w Warszawie, sygn. 55, Zespół Stronnictwo Ludowe 1931-1939. 
1918, s. 5). Redakcja gazety „Piast”, zamieszczając w numerze 50 z 1926 roku obszerne sprawozdanie z V Kongresu PSL „Piast”, wyeksponowała imponujący pochód uczestników Kongresu na Wawel. W pochodzie brało udział kilkanaście tysięcy ludzi, przedstawicieli chłopów z całej Polski. Pochód był przeglądem polskich strojów, sztandarów ludowych z wyhaftowanymi hasłami: „Z Bogiem i wiarą - Lud dla Ojczyzny”, „Żywią i bronią”. Śpiewano pieśni: Bartoszu, Rotę i Jeszcze Polska nie zginęła. W pochodzie brała udział także reprezentacja Hucułów, młodzież wiejska, uniwersytecka, intelektualiści (Brodacki, 1926b, s. 1-2).

Twórcy myśli politycznej stronnictw ludowych niejednokrotnie podkreślali, że kultura ludowa miała duży wpływ na kulturę ogólnonarodową. „Wszyscy nasi poeci szanowali lud wiejski, czerpali z jego pieśni natchnienie do swych dzieł” (Zet, 1918, s. 1). W gazecie „Piast” z grudnia 1926 roku wydrukowano wygłoszone w listopadzie przemówienie kierownika literackiego Teatru im. Słowackiego w Krakowie, poprzedzające wystawioną w teatrze dla uczestników V Kongresu PSL „Piast” sztukę Książe niezłomny, nt. „Jak rola ludu w dziejach polskiej myśli i polskiego uczucia znajdowała odbicie w naszej poezji i twórczości dramatycznej realizowanej na deskach teatru - w dziełach Tetmajera, Słowackiego, Wyspiańskiego, Żeromskiego” i jaką część zasługi miał teatr im. Słowackiego „w dziele pozyskania duszy ludu polskiego" dla idei ogólnonarodowej (Brodacki, 1926c, s. 4). Kilka lat wcześniej, w świątecznym numerze tegoż tygodnika napisano, że szczególnie w polskich kolędach i pastorałkach „(...) pełnych prostoty i rubaszności, a zarazem poezji (...) pochodzących z Bóg wie jak dawnych wieków, zachowała się cała dusza prostacza naszych praojców, zachował się nasz język staropolski i myśl, która się wysilała na godne uczczenie Boga - człowieka i jak największą ofiarność dla niego z owoców swej ciężkiej pracy”. Autorami tych kolęd byli „(...) ludzie, co znali lud kmiecy, jego zwyczaje i gusta". Wszystko w nich bowiem, zauważył publicysta, obracało się wokół stajni, siana, zwierząt i prostego ludu. Dwór i inteligencja w kolędach nie występowała. „Te pieśni przez całe wieki krzepiły naszych praojców, którzy pocieszali się, że kiedyś w drugim bodaj życiu, los im poprawi ten pan, który (...) narodził się w ubóstwie” (Kuba, 1920, s. 1-2). Wojna zniszczyła dorobek kulturalny wsi, tak duchowy, jak i materialny. Należało jak najszybciej zlikwidować straty, zaapelowano w marcu 1920 roku w gazecie „Piast” w artykule Podniesienie kultury wsi (Czado, 1920, s. 7-8). 
Kultura chłopów w pierwszych latach po wojnie spotykała się niejednokrotnie z krytyką. Antoni Bentkowski (1919, s. 10), chłop ze wsi Trojanów, po powrocie do Polski z niewoli niemieckiej był zaskoczony niską kulturą mieszkańców wsi, liczbą analfabetów. Swoje uwagi przekazał redakcji gazety „Piast”. Napisał, że w Zachodniej Europie „zwraca uwagę wysoka kultura i cywilizacja ludu wiejskiego”. Inny - Stanisław Mandziara (1919, s. 6), dostrzegł „(...) jakże wielce różnimy się od narodów zachodnich pod względem kultury i oświaty, (...) u nas o szkołę nikt się nie troszczy (...)”. Na łamach jednej z gazet ludowych wezwał chłopów, by po wsiach zakładali szkoły, czytelnie, domy ludowe. Takie działanie, jego zdaniem, zlikwidowałoby nędzę i „doprowadzi do dobrobytu”. Natomiast J.K. Tatara (1918, s. 8) zauważył, że to w czasie wojny chłopi „zatracili kulturę i postęp". Uwagami podzielił się z czytelnikami. Zadał pytanie: „Czy nie ma już naszego poczciwego, polskiego ludu?” J. Kapuściński (1926, s. 10), chłop inteligent, zwrócił się w liście do młodzieży wiejskiej spędzającej czas „bezproduktywnie”, by zmieniła tryb swojego życia - uczyła się, czytała książki, gazety, pisała, zajęła się rzemiosłem. Wspominał, że dawniej „w zimie ludzie spędzali czas produktywnie, (...) Teraz się obijają”. Tak duża gromada chłopów, „jeśli nie jest oświecona” i pracowita „nie jest nic warta” - stwierdził. Korespondenci byli jednomyślni: kultura wsi w znacznej mierze zależała od jej mieszkańców (J.M., 1918, s. 86-87; Grabski, 1928).

W latach trzydziestych XX wieku wielu działaczy ludowych dostrzegało już wyższy poziom życia większości chłopów: „(..) chłop jest już inny (...). Zmieniło się wiele w wyglądzie wsi” (Kasprzyk, 1938, s. 3). Nie widać już było różnicy w ubiorze między stanami, domy chłopskie były lepiej wyposażone niż przed laty, likwidowano strzechę. „Tędy prowadzi droga do wyższej kultury wiejskiej, do większego liczenia się przez naród z wieśniakami", napisał autor felietonu Kultura wsi (Redakcja, 1930b, s. 3). W gazecie systematycznie informowano również o wystawach obrazujących życie wsi, jej dorobek społeczny, gospodarczy, kulturalno-oświatowy (Redakcja, 1937a, s. 8). Publicyści związani z ruchem ludowym zaapelowali do inteligencji wiejskiej, by przyczyniła się do „podniesienia kultury duchowej i materialnej wsi” (Tatara, 1918, s. 8; Rączkowski, 1919, s. 7; Rouppertowa, 1919, s. 2-3; Komar, 1919, s. 7; Gołba, 1920, s. 14-15; Venus, 1935, s. 7).

Działalność teatrów i chórów wiejskich, a także literatów i twórców ludowych szczególnie wspomagało PSL „Piast” (Migawa, 1921, s. 15; Redakcja, 
1921, s. 12; 1922, s. 9-10; 1929b, s. 6). Od 1920 roku Stronnictwo wydawało miesięcznik „Ogniwo”, który skupiał „najwybitniejszych działaczy i pisarzy ludowych”, a poświęcony był „(...) ogólnej kulturze budzącego się społeczeństwa” (Redakcja, 1920c, s. 18). Z inicjatywy Andrzeja Średniawskiego utworzono w Krakowie fundację „Dom Ludowy Wisła”, wspierającą kulturę ludową. Jej zarząd mieścił się w budynku o takiej samej nazwie. Fundacja zajmowała się propagowaniem kultury, sztuki, oświaty i rzemiosła ludowego. Reklamowała działalność ludności wiejskiej w zakresie sztuki stosowanej w takich gałęziach jak tkactwo, koronkarstwo, kilimkarstwo, wycinkarstwo, hafciarstwo, garncarstwo, wyroby ze skóry, drewna, metalu, słomy itp. W pomieszczeniach budynku fundacji miały siedzibę między innymi towarzystwa ludowe i wydawnictwa, publikujące dla ludności wiejskiej książki, obrazy, kalendarze itp. (Bardel, 1926, s. 10). Na łamach prasy ludowej zamieszczano informacje o ludowych rzemieślnikach, którzy zajmowali się rękodziełem artystycznym i drobnym przemysłem domowym. Wytwórczość ta przynosiła pracę i zarobek niezamożnym mieszkańcom wsi i małych miasteczek. Świadczyła również o narodowej specyfice polskiej sztuki użytkowej. Wykazywała wartości artystyczne tkwiące w warstwie chłopskiej (Redakcja, 1920b, s. 9; Burszta, 1985, s. 266).

Twórcy myśli politycznej partii ludowych, odnosząc się do kultury chłopskiej, nazwali ją „,samorodną, czystą, kryształową, silną i piękną twórczością duszy chłopskiej”. Wyzwoliła ona bowiem u chłopów aktywność twórczą w wyrażaniu swego życia. Artyści ludowi wywodzili się w większości z biedoty wiejskiej i z powodu trudnych warunków materialnych nie mieli możliwości rozwijania i kształcenia swych „nieprzeciętnych” zdolności literackich, malarskich, muzycznych itp. Ich talent „wyładowywał się” na układaniu weselnych przyśpiewek, graniu na weselach, rzeźbieniu lub malowaniu świątków. Wojciech Breowicz (1933, s. 5) z Krosna przedstawił sytuację Jantka z Bugaja (1926, s. 7; 1929a, s. 1), chłopskiego poety, który „przymierał głodem”.

Literaci ludowi próbowali stworzyć własne pismo. Powstał „Lirnik”, który z braku funduszy upadł. Znaleźli się w końcu sponsorzy, którzy zadeklarowali finansowanie pisma chłopskich literatów stwierdzając, że „twórczość ludowa ma wielką wartość”. W kwietniu 1935 roku poinformowano o „nieprzeciętnym talencie literackim, góralu - Stanisławie Nędzy (1935, s. 7). Gazeta 
donosiła, że „gospodarzył on na trzech morgach lichej ziemi (...), bieda u niego aż piszczy. (...) twórz bracie, jak dzieci głodne i obdarte!”. Swoją trudną sytuację przedstawił poeta w wierszu Przed muzyka. Działacze ludowi zabiegali o pieniądze na zasiłki dla literatów ludowych w Funduszu Kultury i Sztuki.

Zdarzało się, że ktoś zdolności ludowych artystów zauważył:,Popatrzcie, jaki ten Boży ludek ma swoją cudowną kulturę". Poza tą grupą znajdowali się wykształceni, wybitni twórcy, również pochodzący z ludu, ,którym się udało”, a także i tacy, którzy nie pochodzili z chłopów, ale utrzymywali twórczą więź z kulturą chłopską (Redakcja, 1935a, s. 10).

Od 1935 roku do „Piasta” i „Śląskiej Gazety Ludowej” był dołączony miesięczny dodatek literacko-artystyczny - „Nurty”. Znajdowały się w nim aktualności kulturalne, wśród nich np.informacja o działającym w Warszawie Instytucie Teatrów Ludowych, wydającym gazetę ,"Teatr Ludowy”, redagowaną od 1926 roku przez prezesa Instytutu - Jędrzeja Cierniaka. Cierniak stworzył koncepcję teatru dla chłopów. Rozumiał odsuniętą wieś od udziału w dobrach kultury narodowej, ponieważ jako chłop z pochodzenia sam tego doświadczył. Buntował się przeciwko „tandecie” kulturalnej, którą ",karmiono” lud. Zmierzał do tego, by w teatrze ludowym w sztuce teatralnej znalazły się takie wartości, które dawałyby możliwość pełnego udziału w życiu kulturalnym również chłopom. Spośród pism literackich redakcje rekomendowały „Wieś Jej Pieśń” - organ Związku Literatów Ludowych w Polsce. Miesięcznik wydawany był w Małopolsce we wsi Naprawa k. Jordanowa przez Antoniego Olchę i Jantka z Bugaja. W 1935 roku poinformowano zainteresowanych o powstałym w Krakowie Związku Zawodowym Literatów Ludowych, gdzie „(...) zgrupowani są poeci i malarze, których tematem twórczości jest wieś”. Komitet organizacyjny Związku stanowili: „Jantek z Bugaja, Franc. Macak, Wojciech Skuza i Ant. Olcha" (Redakcja, 1935b, s. 10; 1935c, s. 8; Burszta, 1985, s. 276). Były to nazwiska znane w środowisku twórców ludowych.

Wśród często publikowanych w pismach ludowych utworów chłopów literatów były wiersze: Muchy (1920, s. 13), Stanisława Sochackiego (1926, s. 8), Jantka z Bugaja (1926, s. 7; 1929b, s. 1; 1929c, s. 3), Nędzy-Kubińca (1935, s. 10), Władysława Orkana, Jana Kasprowicza, Wojciecha Breowicza (1933, s. 5), Wojciecha Skuzy (Redakcja, 1937b, s. 5). Szczególnym szacunkiem darzono chłopskich literatów-intelektualistów Jana Kasprowicza 
i Władysława Orkana. Kasprowicz w utworze Mój świat, zawierającym „pieśni na gęśliczkach i malowanki na szkle”, wyraził wiarę w narodową siłę tkwiącą w masach chłopskich. To on w wierszu Oni i my stwierdził: „Jest w ludzie siła niespożyta, zbawienie leży pod siermięgą”. Nadając w 1937 roku jego imię Uniwersytetowi Ludowemu w Nietażkowie, ,dano wyraz czci i hołdu dla Jana Kasprowicza, chłopskiego geniusza”. Sprawozdanie z uroczystości zamieściła gazeta „Piast” w numerze 28 w lipcu 1937 roku. „Kasprowicz wypowiadał się kunsztownym językiem, a pieśni ludowe często były mu wzorcem" - napisano (Redakcja, 1937b, s. 5; Burszta, 1985, s. 234).

Kultura chłopska, zwłaszcza folklor, były tworzywem literackim Władysława Orkana powieściopisarza, nowelisty, poety, dramaturga i publicysty, pochodzącego z biednej góralskiej rodziny. Jego twórczość zyskała w okresie dwudziestolecia międzywojennego duży rozgłos i uznanie. Orkan upowszechnił w społeczeństwie polskim rozszerzone i pogłębione spojrzenie na kulturę chłopską. Był to nowy rodzaj ludowości, ujawniony przez wybitnego inteligenta, człowieka z ludu (Burszta, 1985, s. 237-238; Redakcja, 1927, s. 3). Wśród nadsyłanych przez chłopów do prasy ludowej wierszy na uwagę zasługuje poemat emigranta Kazimierza Ciepieli z Chicago (1929, s. 5) - Wspomnienie o mej wiosce:

Tam w Ojczyźnie, w polskiej krainie,

Dwu sławnych rzek wstęgą opasana,

Między wzgórzami w pięknej dolinie,

Jest cicha wieś rodzinna - ukochana.

Wiersze poetów ludowych pełne były buntu, goryczy i żalu na ciężką dolę chłopa, a równocześnie miłości do pięknej ojczystej ziemi. Znanym chłopskim politykiem, publicystą i pisarzem był Jakub Bojko. W opowiadaniach ukazywał chłopskich bohaterów z minionych wieków, „zapomnianych przez ówczesną historię" i literaturę. Inspiracją jego twórczości były ludowe przekazy ustne (Bojko, 1926, s. 5-8).

Tematyka twórczości poetów i pisarzy ludowych dotyczyła ważnych wydarzeń religijnych, historycznych, społecznych i politycznych. Szczególnie wiele miejsca na łamach prasy wydawanej przez stronnictwa ludowe w latach 1919-1920 poświęcono chłopom - obrońcom ojczyzny. Umieszczano 
opowiadania i wiersze, opiewające waleczność ludu, np. w wierszach $\mathrm{Na}$ bój i Pieśń odpustowa dziadowska samorodni poeci ludowi przekonywali, że dzielny chłop żołnierz „w niebie ma pierwszeństwo nawet przed królami” (Byczek, 1920, s. 3; Francesco, 1920, s. 3; J.M., 1918, s. 337-338). Nieznany autor w wierszu Co mówi do ludowca kosa stwierdził, że kosa wzywa chłopa, by „bił wroga, stojącego u proga” (Redakcja, 1920a, s. 13). Teresa Niwicka (1920, s. 3) poświęciła swój utwór Wincentemu Witosowi. Poeta Mucha (1920, s. 13) w wierszu Znasz - li ten kraj? zadał pytanie:

Czy znasz ten kraj (...)

Gdzie rządzą dziś

Sowieckie bolszewiki.

W związku z wojną polsko-radziecką powstał też wiersz Sz. Orzecha (1920, s. 3) Ojczyzna woła. Podczas secesji Jakuba Bojki Jantek z Bugaja (1929c, s. 3) napisał poemat, w którym przedstawił swoje oburzenie.

Z literatury polskiej twórcy ludowej myśli politycznej upodobali sobie tych autorów spoza warstwy chłopskiej, którzy pisali o wsi i chłopach, a w swej twórczości niejednokrotnie wykorzystywali folklor i ludowy przekaz baśniowy. O nich wspominano i drukowano ich utwory w wydawnictwach ludowych (Lasocki, 1934, s. 3; Redakcja, 1926b, s. 4). Byli to Adam Mickiewicz, Juliusz Słowacki, Ignacy Krasiński, Włodzimierz Tetmajer, Maria Dąbrowska (M.B., 1937, s. 7), Maria Konopnicka (1926, s. 13), Aleksander Świętochowski (Matysik, 1938, s. 7; Redakcja, 1938, s. 3), Józef Ignacy Kraszewski (1928, s. 3). Szczególną estymą było otaczane dzieło Chłopi Władysława Reymonta - epopeja wsi polskiej. Autor opisał życie mieszkańców wsi Lipce na tle przyrody i w łączności z pracą. Tym dziełem Reymont uzmysłowił społeczeństwu istotę kultury ludowej, która była nie tylko cechą społeczności wiejskiej, lecz stała się w znacznej mierze własnością całego społeczeństwa polskiego. Nagroda Nobla przyznana autorowi w 1924 roku stała się impulsem do zorganizowania $\mathrm{w}$ dniach 15 i 16 sierpnia 1925 roku, pod patronatem PSL „Piast”, wielkich uroczystości w Wierzchosławicach i Krakowie z udziałem noblisty. W uroczystościach wzięli udział czołowi przedstawiciele Stronnictwa oraz kilkadziesiąt tysięcy chłopów (Jakubowska, 1995, s. 48; Witos, 1924, s. 1; 1925, s. 1; Burszta, 1985, s. 240). 
Działacze i sympatycy ruchu ludowego niejednokrotnie ubolewali, że „literatura polska posiada na ogół wybitne cechy społecznego arystokratyzmu”. Rozwijała się w atmosferze wyłączności stanowej, była też zgodnie z tradycjami szlacheckimi „literaturą panów”, a różnica kulturowa dzieląca chłopa i ziemianina była zbyt wielka, żeby ją w krótkim czasie zniwelować. Powodem licznych dysproporcji kulturowych w Polsce był, jak podkreślano, renesans szlachetczyzny datujący się od połowy lat dwudziestych XX wieku bujny rozkwit „kultury szlacheckiej” (J.B., 1937, s. 7; Langier, 1934, s. 4).

Politycy ruchu ludowego zwracali uwage, że okazałe pomniki materialnej kultury polskiej (budowle, parki, ogrody) zostały wzniesione „krwawym potem wieśniaczego ludu" (Kostrzewa, 1928, s. 1). Profesor Sebastian Flisak (1939, s. 5) w artykule Idealizm naszego ludu. Przydrożne i polne kapliczki, opublikowanym w numerze 15 „Piasta” z 1939 roku, podkreślił, że chęć przeżycia siebie przez „dzieło myśli lub ręki” w jednym szeregu stawia wielkich twórców i rzemieślników, magnatów, fundatorów kościołów i klasztorów, obok chłopów poddanych. Różnica w realizowaniu intencji zależała od funduszy i stopnia kultury, zarówno twórców jak i mecenasów.

Ludowcy, krytykując dysproporcje kulturowe w Polsce, zwrócili uwagę, że „W dzisiejszej (...) dobie chłop polski i chłopska literatura całkiem wyszły z mody. (...) Nowe warstwy i nowi panowie (...) nie cierpią chłopa ani w książce, ani (...) nigdzie. Brzydzą się nim” (Redakcja, 1927, s. 3; Brodacki, 1926a, s. 1; J.B., 1937, s. 7). Tadeusz Janiszewski (1926a, s. 3; 1926b, s. 3), były minister zdrowia w rządzie Ignacego Paderewskiego, zaapelował w 1926 roku w artykułach na temat ideologii ruchu ludowego, że stronnictwa ludowe powinny zaangażować się w tworzenie specjalnej, osobnej kultury wiejskiej. Propagatorzy kultury chłopskiej niejednokrotnie zwracali uwagę, że „(...) wieś polska powinna tworzyć własną kulturę, odpowiadającą twardym warunkom jej życia” (P.B., 1935, s. 5).

\section{Uwagi końcowe}

Kultura ludowa we wczesnym średniowieczu była kulturą samoistną, pełną i jedyną. W ciągu feudalnego rozdzielenia się społeczeństwa na stany, a jego kultury na wiele nurtów, stała się jednym z nich - subkulturą. W końcu zaczęła zlewać się w jedno łożysko kultury ogólnonarodowej, wnosząc do 
niej swoje wielowiekowe wartości. Symbolem szczęśliwego okresu dziejów chłopskich i piastowskiej, jedynej chłopskiej kultury, jako czysto-słowiańskiej, był przejawiający się w literaturze motyw Piasta-Kołodzieja, legendarnego założyciela dynastii królewskiej i twórcy państwa polskiego, symbolu polskiego chłopa pełnego godności, nie tego uciemiężonego. Do takiego symbolu w piśmiennictwie ludowym urósł Witos. Legendarny Piast w podaniach - mitach ukazał twarz przedstawiciela godnego stanu chłopskiego, a chłopska wieś okazywała się potęgą polityczną i kulturową (Burszta, 1985, s. 8; Drwal, 1920a, s. 6-8; 1920b, s. 12-13).

Obrazowanie kultury chłopskiej w myśli politycznej ruchu ludowego miało aspekt społeczno-polityczny. Chłopi, najliczniejsza warstwa społeczeństwa, stanowili jego podstawowy zrąb, a więc ich kultura powinna stanowić podstawę kultury narodowej - podkreślano. Nadal ciążyła tradycja podtrzymywana przez ówczesne upośledzenie chłopów - rzeczywistą „pańskość” i „szlacheckość” tej wyższej, elitarnej kultury. Teoria dwóch kultur, chłopskiej i pańskiej powstała w okresie romantyzmu. Towarzyszyła od tamtego czasu dziejom myśli społeczno-politycznej, stanowiła też inspirację dla wielu dzieł literackich, muzycznych i plastycznych. Za pośrednictwem czasopism skierowanych do chłopów, partie ludowe dążyły, by u ludu wiejskiego, w miejsce dotychczasowego upośledzenia, poniżenia i poczucia małowartościowości, wystąpiła duma z własnej kultury (Burszta, 1985, s. 163-164, 253, 280; Waleron, 1927, s. 1-2).

Polityczny ruch ludowy w II Rzeczypospolitej był przejawem świadomości chłopów. W sytuacji, gdy kultura narodu dzieliła się na dwie - kulturę „pańską" i „chłopską”, ruch ludowy zmierzał do nadania kulturze chłopskiej wartości ogólnonarodowych. Stąd pochodziły: swoisty mistycyzm w ocenie wartości tej kultury i demonstracyjne wręcz ukazywanie jej elementów; strojów, pieśni, obrzędów, gwary itp. Odtwarzano czy raczej przetwarzano agrarystyczne obrzędy w inscenizacjach teatralnych, mające nawiązywać do okresu wspólnoty słowiańskiej i do Polski piastowskiej (Burszta, 1985, s. 279-280). W działalności stronnictw ludowych stawiano sobie ważny cel, by, zamiast dotychczasowego upośledzenia, poniżenia i poczucia małowartościowości, wystąpiła u chłopów duma z własnej kultury.

Niepodległe dwudziestolecie przejęło cały bagaż dotychczasowej ludowości i jeszcze go wzbogaciło. W tamtym okresie chłopi uświadomili sobie 
własną odrębność nie tylko jako warstwa, ale i kulturową. Uświadomienie to było najwyższe u chłopskich działaczy, głównie u inteligentów wywodzących się ze wsi i związanych z kulturą ludową. Nastąpiło u nich - pod wpływem ideologii ruchu ludowego, regionalizmu i doktryny agraryzmu - inne widzenie świata (Burszta, 1985, s. 284; Młot, 1927, s. 345-346; Dąbski, 1927, s. 1-2). Kultura ludowa była „przechowalnią” istotnych wartości, które w miastach ulegały szybszym przemianom. Była to ważna rola w utrzymywaniu ciągłości i tożsamości kultury narodowej (Szczepański, 1988, s. 56).

\section{DR HAB. MARCIN WICHMANOWSKI}

Wydział Politologii i Dziennikarstwa

Uniwersytet Marii Curie-Skłodowskiej

Pl. Litewski 3, 20-080 Lublin

marcin.wichmanowski@poczta.umcs.lublin.pl

\section{Bibliografia}

\section{Wykaz źródeł i literatury}

\section{Źródła archiwalne}

Archiwum Akt Nowych w Warszawie, sygn. 110/I, II, V, Stronnictwo Ludowe 1932-1939 (mf. 2530).

Archiwum Zakładu Historii Ruchu Ludowego w Warszawie, sygn. 55, Zespół Stronnictwo Ludowe 1931-1939.

\section{Źródła drukowane}

Program Polskiego Stronnictwa Ludowego Piast. (1920, 15 lutego). W: S. Lato, W. Stankiewicz (1969). Programy stronnictw ludowych: Zbiór dokumentów (177-181). Warszawa: Państwowe Wydawnictwo Naukowe.

Program Polskiego Stronnictwa Ludowego Wyzwolenie. (1925, 16 marca). W: S. Lato, W. Stankiewicz (1969). Programy stronnictw ludowych: Zbiór dokumentów (229-244). Warszawa: Państwowe Wydawnictwo Naukowe.

Program Stronnictwa Chłopskiego. (1927, czerwiec). W: S. Lato, W. Stankiewicz (1969). Programy stronnictw ludowych: Zbiór dokumentów (281-287). Warszawa: Państwowe Wydawnictwo Naukowe.

Program Stronnictwa Ludowego. (1931, 15 marca). W: S. Lato, W. Stankiewicz (1969). Programy stronnictw ludowych: Zbiór dokumentów (299-311). Warszawa: Państwowe Wydawnictwo Naukowe. 
Program Stronnictwa Ludowego. (1935, 8 grudnia). W: S. Lato, W. Stankiewicz (1969). Programy stronnictw ludowych: Zbiór dokumentów (313-318). Warszawa: Państwowe Wydawnictwo Naukowe.

\section{Artykuły prasowe}

A.P. (1932, 27 marca). Kamień Kościuszki. Piast. 13, s. 3.

Babinianin z Babicy w rzeszowskim, Czytelnik z Cyranki w mieleckim (1919, 17 sierpnia). Listy do redakcji. Piast, 33, s. 10.

Bardel, F. (1926, 4 kwietnia). Dom Ludowy Wisła w Krakowie. Piast, 14, s. 10.

Bentkowski, A. (1919, 7 września). List do redakcji. Piast, 36, s. 10.

Bogusławski, A. (1923, 20 maja). O organizacji skarbowej w państwie, cz. 6. Wydatki na cele kulturalne i gospodarcze. Siew, 19/20, s. 8.

Bojko, J. (1926, 28 marca). Michałko. Bohater chłopskich wojen szwedzkich. Piast, 13, s. $5-8$.

Bożek, E. (1937, 11 grudnia). Niecodzienna uroczystość w powiecie tarnobrzeskim. Piast, 28, s. 4.

Breowicz, W. (1933, 9 lipca). W sprawie organu twórczości chłopskiej, Piast, 28, s. 5.

Brodacki, J. (1926a, 25 lipca). Antichamizm. Piast, 31, s. 1.

Brodacki, J. (1926b, 5 grudnia). Wyczerpujące i dokładne sprawozdanie z przebiegu obrad V Kongresu PSL Piast - Pochód na Wawel. Piast, 50, s. 1-2.

Brodacki, J. (1926c, 5 grudnia). Przedstawienie w teatrze miejskim. Piast, 50, s. 4.

Bujak, F. (1939, listopad). Szlachecka czy chłopska kultura. Wieś i Państwo, 7, s. 489-490.

Byczek, W. (1920, 8 sierpnia). Na bój. Piast, 32, s. 3.

Ciepiela K. z Chicago (1929, 18 sierpnia). Wspomnienie o mej wiosce. Piast, 33, s. 5.

Czado, A. (1920, 28 marca). Podniesienie kultury wsi. Piast, 13, s. 7-8.

Dąbski, J. (1927, 6 listopada). A gdzież chłopscy inteligenci. Gazeta Chłopska, 45, s. 1-2.

Drwal, A. (1920a, 7 listopada). Zagadnienia polityki ludowej (Tło historyczne. Dążenia wyzwoleńcze ludu w Polsce. Wskazania na przyszłość). Piast, 45, s. 6-8.

Drwal, A. (1920b, 14 listopada). Zagadnienia polityki ludowej (Tło historyczne. Dążenia wyzwoleńcze ludu w Polsce. Wskazania na przyszłość) cd. Piast, 48, s. 12-13.

Dunikowski, J. (1919, 14 września). Na cele oświaty. Piast, 37, s. 8.

Dziewczyna wiejska z Kobierzyc, S.M. Przyszowa (1919, 8 czerwca). Życie gospodarcze i umysłowe wsi - Listy: Informacja o wystawieniu sztuki Wł. Anczyca. Piast, 23, s. 14.

Flisak, S. (1939, 9 kwietnia). Idealizm naszego ludu. Przydrożne i polne kapliczki. Piast, 15 , s. 5 .

Francesco (1920, 8 sierpnia). Jako żołnierz ma w niebie pierwszeństwo przed królami (pieśń odpustowa dziadowska). Piast, 32, s. 3.

Gołba, Ks. (1920, 19 września). Ludowe szkoły rolnicze. Piast, 38, s. 14-15.

J.B. (1937, 26 grudnia). Chłopi w Polsce wczoraj i dziś. Piast, 50, s. 8.

J.M. (1918a, 3 marca). W sprawie zakładania bibliotek. Wyzwolenie, 9, s. 86-87.

J.M. (1918b, 22 września). Co nam mówią wskazania dziejów Polski. Wyzwolenie, 38, s. 337-338.

Janiszewski, T. (1926a, 14 lutego). Ideologia ruchu ludowego. Piast, 7, s. 3.

Janiszewski, T. (1926b, 28 lutego). Ideologia ruchu ludowego (c.d.). Piast, 9, s. 3.

Jantek z Bugaja (1926, 3 października). Hej orły. Piast, 41, s. 7. 
Jantek z Bugaja (1929a, 6 stycznia). 1929. Piast, 1, s. 1.

Jantek z Bugaja (1929b, 6 stycznia). O moi bracia... Piast, 1, s. 1.

Jantek z Bugaja (1929c, 14 kwietnia). Judasze. Piast, 15, s. 3.

Kapuściński, J. (1926, 3 stycznia). Moja gawęda. Piast, 1, s. 10.

Kasprzyk, L. (1938, 6 listopada). Przechodzić przez strumień: O ile zmieniła się wieś?

Piast, 45, s. 3.

Kolanko, J. (1927, 9 stycznia). Walka o nowy ustrój szkolny. Gazeta Chłopska, 2, s. 3.

Komar, T. (1919, 21 grudnia). Do młodych sióstr i braci. Piast, 51, s. 7.

Konopnicka, M. (1926, 21 listopada). W rocznicę Szopena. Piast, 48, s. 13.

Kostrzewa, J. (1928, 3 czerwca). Staniemy do ostatecznej rozgrywki. Piast, 23, s. 1.

Kraszewski, J., I. (1928, 15 stycznia). Stara baśń. Piast, 3, s. 3.

Kuba (1920, 26 grudnia). W dzień Bożego Narodzenia. Piast, 52, s. 1-2.

Langier, A. (1934, 7 styczeń). Kastowość inteligencji. Zielony Sztandar, 3, s. 4.

Lasocki, Z. (1934, 8 kwietnia). Tylko nie przesadzać. Piast, 21, s. 3.

Liszka, P. (1927, 22 maja). 3-ci Maja w Dobrej, pow. Limanowski. Piast, 20, s. 7.

Lubas, W., Czarnota, J. (1919, 11 maja). Życie gospodarcze i umysłowe wsi - Listy. Piast, 19 , s. 8.

M.B. (1937, 9 maja). M. Dąbrowska - przyjaciółka wsi. Piast, 16, s. 7.

Mandziara, S. (1919, 24 sierpnia). Godne naśladowania. Piast, 34, s. 6.

Matysik, S. (1938, 22 maja). A. Świętochowski znakomity pisarz - myśliciel - publicysta. Piast, 21, s. 7.

Migawa, J. (1921, 9 stycznia). Nowa sztuka ludowa Konstantego Krumłowskiego. Piast, 2, s. 15.

Młot, J. (1927, 5 czerwca). Co można robić przez samorządy. Wyzwolenie, 35, s. 345-346.

Moskal, M., Jarosz, J. (1926, 3 stycznia). Koło młodzieży w Mikołajowicach. Piast, 1, s. $10-11$.

Mucha (1920, 12 września). Znasz - li ten kraj? Piast, 37, s. 13.

Nędza, S. (1935, 7 kwietnia). Przed muzyką. Piast, 14, s. 7.

Nędza-Kubiniec, S. (1935, 27 stycznia). Na muzyce. Piast, 4, s. 10.

Niwicka, T. (1920, 29 sierpnia). Wincentemu Witosowi. Piast, 35, s. 3.

Orzech, S. (1920, 15 sierpnia). Ojczyzna woła. Piast, 33, s. 3.

P.B. (1935, 15 grudnia). O chłopskie podłoże kultury narodowej. Piast, 50, s. 3.

Pluta, A. (1919, 7 września). Wrażenia z Zakopanego. Piast, 31, s. 3-4.

Rączkowski, J. (1919, 14 grudnia). Do chłopskich synów uczących się w szkołach. Piast, 50, s. 7.

Redakcja (1918, 24 listopada). O ubiory Polskie... Piast, 47, s. 5.

Redakcja (1919a, 30 marca). Piastowy dzień w Krakowie. Piast, 13, s. 1-3.

Redakcja (1919b, 30 marca). Przyjęcie delegacji. Piast, 13, s. 3.

Redakcja (1919c, 25 maja). Obchody uchwalenia Konstytucji 3-Maja (tarnowskie, strzyżowskie, jarosławskie). Piast, 21, s. 14-15.

Redakcja (1919d, 14 września). Pochód na Wawel. Piast, 37, s. 1-2.

Redakcja (1920a, 19 września). Co mówi do ludowca kosa. Piast, 38, s. 13.

Redakcja (1920b, 29 sierpnia). Popłatne zajęcie. Piast, 35, s. 9.

Redakcja (1920c, 31 października). Do działaczy ludowych i inteligencji PSL! Piast, 44, s. 18. 
Redakcja (1921, 16 stycznia). O kulturę ludu. Piast, 3, s. 12.

Redakcja (1922, 1 stycznia). Kurs dramatyczny dla kierowników teatrów włościańskich.

Piast, 1, s. 9-10.

Redakcja (1926a, 31 stycznia). Kursy słowiańskiej kultury. Piast, 5, s. 10.

Redakcja (1926b, 5 grudnia). Przedstawienie w Teatrze miejskim. Piast, 50 , s. 4.

Redakcja (1927, 23 sierpnia). Precz z Witosem znaczy precz z chłopami. Piast, 35, s. 3.

Redakcja (1929a, 4 sierpnia). Nie samym chlebem żyje człowiek. Piast, 31, s. 2.

Redakcja (1929b, 17 listopada). Konkurs na sztukę ludową. Piast, 46, s. 6.

Redakcja (1930a, 30 marca). W teatrze miejskim - uroczyste przedstawienie sztuki Anczyca „Kościuszko pod Racławicami”. Piast, 13, s. 3.

Redakcja (1930b, 6 lipca). Kultura wsi. Piast, 27, s. 3.

Redakcja (1935a, 27 stycznia). Typy literatów w Polsce - po dwu stronach barykad. Piast, 4, s. 10.

Redakcja (1935b, 27 stycznia). Kronika literacka: Nurt. Piast, 4, s. 10.

Redakcja (1935c, 17 lutego). Ważniejsze wydarzenia w świecie literackim w Polsce w 1934 roku. Mirek - Związek Zawodowy Literatów Ludowych w Polsce. Piast, 7, s. 8.

Redakcja (1935d, 21 lipca). Wielka manifestacja wsi polskiej. Piast, 29, s. 3.

Redakcja (1935e, 4 sierpnia). Życie na wsi... Piast, 31, s. 2.

Redakcja (1937a, 13 czerwca). Praca i kultura wsi. Piast, 24, s. 8.

Redakcja (1937b, 11 lipca). Maria Kasprowiczowa w gronie młodzieży wiejskiej. Piast, 28, s. 5.

Redakcja (1938, 8 maja). Aleksander Świętochowski 1849-1938. Piast, 19, s. 3.

Rouppertowa (1919, 14 grudnia). O szkołach rolniczych. Piast, 50, s. 2-3.

Sochacki, S. (1926, 4 kwietnia). I błogosławi... Piast, 14, s. 8.

Tatara, J., K. (1918, 8 grudnia). Ból serce ściska, rozpacz człowieka ogarnia. Piast, 49, s. 8. Venus (1935, 16 czerwca). Dyplomowane chamy. Piast, 24, s. 7.

Waleron, A. (19 III 1927, 19 marca). Organizacja młodzieży chłopskiej. Gazeta Chłopska, 11, s. $1-2$.

Wieski, J. (1929, 6 stycznia). Z ruchu młodzieży wiejskiej w Polsce. Piast, 1, s. 3.

Witos, W. (1924, 23 listopada). Czcigodny Panie! List do Władysława Reymonta na wieść o przyznaniu mu nagrody Nobla. Piast, 47 , s. 1.

Witos, W. (1925, 23 sierpnia). Podziękowanie. Piast, 34, s. 1.

Zet (1918, 1 grudnia). Stosunek inteligencji do ludu. Piast, 48, s. 1.

\section{Opracowania}

Budrewicz, Z. (1996). Treści humanistyczne w ludowych szkołach rolniczych $\mathrm{z}$ lat 1918-1932.W: A. Meissner (red.). Chłopi-naród - kultura, t. 4,(221-228). Rzeszów: Wydawnictwo Wyższej Szkoły Pedagogicznej w Rzeszowie.

Bukraba-Rylska, I. (2008). Socjologia wsi polskiej. Warszawa: Wydawnictwo Naukowe PWN SA.

Burszta, J. (1985). Chłopskie źródła kultury. Warszawa: Ludowa Spółdzielnia Wydawnicza. Chrobak, T. (1998). Filozoficzne przesłanki agraryzmu. Studium wybranych zagadnień. Rzeszów: Wydawnictwo Wyższej Szkoły Pedagogicznej.

Cimek, H. (2007). Myśl polityczna stronnictw ludowych w kwestii niepodległości Polski w latach 1914-1919. Warszawa: Wydawnictwo Wyższej Szkoły Cła i Logistyki. 
Czarnota, A. (1988). Problemy syntezy polskiej myśli politycznej - rozważania wstępne. W: W. Wrzesiński (red.). Polska myśl polityczna XIX i XX wieku, t. 7: Państwo w polskiej myśli politycznej (265-279). Wrocław-Warszawa-Kraków-Gdańsk-Łódź: Wydawnictwo Ossolineum.

Dejworek, B. (1965). Ignacy Solarz jako wychowawca i działacz społeczny. W: F. Popławski, S. Dyksiński (wybór i oprac.). Ignacy Solarz i jego uniwersytet ludowy 1924-1939. Materiaty z seminarium naukowego odbytego w Warszawie 5 i 6 X 1962 r. (16-51). Warszawa: Ludowa Spółdzielnia Wydawnicza.

Garlicki, A. (1966). Powstanie Polskiego Stronnictwa Ludowego Piast 1913-1914. Warszawa: Ludowa Spółdzielnia Wydawnicza.

Garlicki, A. (1981). Wstęp. W: A. Garlicki (red.). Przewroty i zamachy stanu: Europa 1918-1939 (5-9). Warszawa: Spółdzielnia Wydawnicza Czytelnik.

Grabski, W. (1928). Kultura wsi polskiej i nauczanie powszechne. Warszawa: Nakładem Księgarni F. Hoesicka.

Hampel, J. (2002). Koncepcja Polski ludowej w programach i działalności ruchu ludowego w latach 1918-1947. W: A. Kołodziejczyk, W. Paruch (red.). Dzieje i przyszłość polskiego ruchu ludowego, t. 1: Od zaborów do okupacji (1895-1945) (27-38). Warszawa: Ludowa Spółdzielnia Wydawnicza.

Jachymek, J. (1983). Myśl polityczna PSL Wyzwolenie 1918-1931. Lublin: Wydawnictwo Lubelskie.

Jachymek, J. (1993). Neoagraryzm i trzecia droga. Przebudowa i walka o nowa Polskę, Lublin: Wydawnictwo Czas.

Jachymek, J. (2001). Ruch ludowy. W: J. Jachymek, W. Paruch (red.). Więcej niż niepodległość: Polska myśl polityczna 1918-1939 (221-257). Lublin: Wydawnictwo Uniwersytetu Marii Curie-Skłodowskiej.

Jachymek, J. (2002). Ludowcy w pierwszym półwieczu zorganizowanej działalności politycznej. W: A. Kołodziejczyk, W. Paruch (red.). Dzieje i przyszłość polskiego ruchu ludowego, t. 1: Od zaborów do okupacji (1895-1945) (27-38). Warszawa: Ludowa Spółdzielnia Wydawnicza.

Jachymek, J., Paruch, W. (2001). Wstęp. W: J. Jachymek, W. Paruch (red.). Więcej niż niepodległość: Polska myśl polityczna 1918-1939 (9-14). Lublin: Wydawnictwo Uniwersytetu Marii Curie-Skłodowskiej.

Jajecznik, K. (2006). Myśl polityczna - próba standaryzacji badań. Rocznik Nauk Politycznych, 9, 255-270.

Jakubowska, B. (1995). Historiozofia ruchu ludowego w II Rzeczypospolitej. Roczniki Dziejów Ruchu Ludowego, 29, 29-53.

Kopaliński, W. (1967) Słownik wyrazów obcych i zwrotów obcojęzycznych, Warszawa: Wiedza Powszechna.

Kowalski, P. (1996). Kultura ludowa - utopie humanistyki. W: A. Meissner (red.). Chłopinaród - kultura, t. 4: Kultura i oświata wsi (27-40). Rzeszów: Wydawnictwo Wyższej Szkoły Pedagogicznej.

Król, M. (1998). Historia myśli politycznej: Od Machiavellego po czasy współczesne. Gdańsk: Wydawnictwo Arche.

Kuranc-Szymczak, M. (2019). Bohaterowie minionych czasów, W: E. Kirwiel, E. Maj, E. Podgajna, M. Wichmanowski (red.). Myśl polityczna - demokracja - wolność. Księ- 
ga Jubileuszowa dedykowana Profesorowi Janowi Jachymkowi z okazji 80. rocznicy urodzin (213-232). Lublin: Wydawnictwo Uniwersytetu Marii Curie-Skłodowskiej. Łazuga, W. (2013). Kalkulować... Polacy na szczytach C.K. Monarchii. Poznań: Wydawnictwo Zysk i Sk-a.

Łuczak, A. (1982). Społeczeństwo i państwo w myśli politycznej ruchu ludowego. Warszawa: Ludowa Spółdzielnia Wydawnicza.

Maj, E., Wójcik, A. (2008). Wstęp. W: E. Maj, A. Wójcik (red.). Myśl polityczna w Polsce po 1989 roku. Wybrane nurty ideowe (7-11). Lublin: Wydawnictwo Uniwersytetu Marii Curie-Skłodowskiej.

Olszewski, E. (2015). Wybrane problemy myśli politycznej: idea, ideologia, doktryna polityczna. W: E. Maj, E. Kirwiel, E. Podgajna (red.). Myśl polityczna w społeczeństwie informacyjnym (153-174). Lublin: Wydawnictwo Uniwersytetu Marii Curie-Skłodowskiej.

Paruch, W. (1997). Od konsolidacji państwowej do konsolidacji narodowej: Mniejszości narodowe w myśli politycznej obozu piłsudczykowskiego (1926-1939). Lublin: Wydawnictwo Uniwersytetu Marii Curie-Skłodowskiej.

Paruch, W. (1999). Myśl polityczna - refleksje metodologiczne o pojęciu. W: Z.J. Pietraś, A. Wójcik, W. Paruch (red.). Państwo - ludowcy - myśl polityczna (27-39). Lublin: Annales Universitatis Mariae Curie-Skłodowska. Sectio K: Politologia.

Paruch, W. (2004). Między wyobrażeniami a działaniami. Wybrane aspekty przedmiotowe badań politologicznych nad myślą polityczną, Polityka i Społeczeństwo, 1, 9-38.

Paruch, W. (2005). Myśl polityczna obozu piłsudczykowskiego 1926-1939. Lublin: Wydawnictwo Uniwersytetu Marii Curie-Skłodowskiej.

Paruch,W. (2009). Kategorie ekonomiczne a zakres pojęcia „myśl polityczna” - refleksje metodologiczne. W: E. Maj, S. Michałowski, A. Wójcik (red.). Idee - Państwo - Ludowcy. Księga jubileuszowa z okazji 70. rocznicy urodzin Profesora Jana Jachymka (37-46). Lublin: Wydawnictwo Uniwersytetu Marii Curie-Skłodowskiej.

Paruch, W. (2015). Konsekwencje definiowania myśli politycznej dla kwestionariusza badań politologicznych. Humanities and Social Science, 22(1), 157-174.

Podgajna, E. (2011). Stronnictwo Chłopskie (1926-1931). Studium z dziejów myśli politycznej, Lublin 2011: Wydawnictwo Uniwersytetu Marii Curie-Skłodowskiej.

Skarzyński, R. (1990). Intelektualiści a ideologia. Myśl polityczna jako przedmiot badań politologa. Studia Nauk Politycznych, 4-6, 9-27.

Skarzyński, R. (1992). Historia myśli politycznej w ujęciu politologicznym: Zarys koncepcji. Studia Polityczne, 1, 107-119.

Strzelecki, M. (2008). Wizje wychowania społecznego w polskiej myśli politycznej lat 1918-1939. Bydgoszcz: Wydawnictwo Uniwersytetu Kazimierza Wielkiego.

Szaflik, J.R. (1970). Polskie Stronnictwo Ludowe Piast 1926-1931. Warszawa: Ludowa Spółdzielnia Wydawnicza.

Szczepański, J. (1988). Chłopi i kultura chłopska w społeczeństwie polskim. Warszawa: Ludowa Spółdzielnia Wydawnicza.

Szmyd, J. (1996). Tożsamość chłopska - charakter i ethos narodowy - polskość. W: A. Meissner (red.). Chłopi - naród - kultura, t. 4: Kultura i oświata wsi (11-26). Rzeszów: Wydawnictwo Wyższej Szkoły Pedagogicznej. 
Turkowski, R. (1983). Wiejskie organizacje młodzieżowe a wychowanie obywatelskie chłopów w okresie międzywojennym, Przegląd Humanistyczny, 4(211), 83-102.

Wapiński, R. (1987). Badania nad dziejami polskiej myśli politycznej schyłku XIX i XX wieku. Przeglad Humanistyczny, 9(264), 51-70.

Wapiński, R. (1990). Badania nad dziejami polskiej myśli politycznej schyłku XIX i XX wieku W: J. Maternicki (red.). Historia najnowsza jako przedmiot badań i nauczania (169-178). Warszawa: Państwowe Wydawnictwo Naukowe.

Wichmanowski, M. (2010). Działalność i myśl polityczna Aleksandra Bogusławskiego (1887-1963) polityka ruchu ludowego. Lublin: Wydawnictwo Uniwersytetu Marii Curie-Skłodowskiej.

Wichmanowski, M. (2019). Demokracja w myśli politycznej ludowców w okresie międzywojennym: Wybrane problemy. W: E. Kirwiel, E. Maj, E. Podgajna, M. Wichmanowski (red.). Myśl polityczna - demokracja - wolność. Księga Jubileuszowa dedykowana Profesorowi Janowi Jachymkowi z okazji 80. rocznicy urodzin (311-328). Lublin: Wydawnictwo Uniwersytetu Marii Curie-Skłodowskiej.

Wichmanowski, M. (2017). Myśl polityczna Polskiego Stronnictwa Ludowego Piast 1913/14-1931. Lublin: Wydawnictwo Uniwersytetu Marii Curie-Skłodowskiej.

Wichmanowski, M. (2013a). Oświata w myśli politycznej i działalności Aleksandra Bogusławskiego. W: M. Wichmanowski (red.). Nauka, edukacja. Kultura w polskiej myśli politycznej XX i XXI wieku (35-57). Lublin: Wydawnictwo Uniwersytetu Marii Curie-Skłodowskiej.

Wichmanowski, M. (2013b). Wstęp. W: M. Wichmanowski (red.). Nauka, edukacja. Kultura w polskiej myśli politycznej XX i XXI wieku (7-11). Lublin: Wydawnictwo Uniwersytetu Marii Curie-Skłodowskiej.

Wojdyło, W. (1985). Geneza i rozwój polskiego ruchu ludowego w latach 1895-1985. Toruń: Instytut Kształcenia Nauczycieli.

Wójcik, A. (1992). Myśl polityczna Stanisława Augusta Thugutta 1873-1941. Lublin: Wydawnictwo Uniwersytetu Marii Curie-Skłodowskiej.

Zakrzewski, A. (1988). Państwo w programach stronnictw ludowych. W: W. Wrzesiński (red.). Polska myśl polityczna XIX i XX wieku, t. 7: Państwo w polskiej myśli politycznej (121-135). Wrocław-Warszawa-Kraków-Gdańsk-Łódź: Wydawnictwo Ossolineum.

Zieliński, H. (1975). O potrzebie i trudnościach badania dziejów polskiej myśli politycznej. W: H. Zieliński (red.). Polska myśl polityczna XIX i XX wieku, t. 1: Polska i jej sąsiedzi (7-26). Wrocław-Warszawa-Kraków-Gdańsk: Wydawnictwo Ossolineum.

\section{Netografia}

Kultura - pojęcie. Pobrane z: http://polskiwdwunastce.edu.pl/wiedza-o-kulturze/54/ kultura-pojecie.

Kultura jako jedno z podstawowych pojęć humanistyki współczesnej. Pobrane z: http:// etyka.wyklady.org/wyklad/769_kultura-jako-jedno-z-podstawowych-pojec-humanistyki-wspolczesnej.html.

Wokół pojęcia „kultura”. Pobrane z: http://pl.shvoong.com/social-sciences/1929336-wok \%C3\%B3\%C5\%82-poj\%C4\%99cia-kultura/. 